\title{
ENIGMATIC INDUCTION OF CYTOMIXIS IN ALLIUM CEPA ROOT MERISTEM BY AGLAIA EDULIS ROXB. LEAF EXTRACT AND ITS PHYTOCHEMICAL RATIONALE
}

\author{
ARCHANA ELAMKULAM RAVINDRAN*, JOHN ERNEST THOPPIL \\ Department of Botany, University of Calicut, Malappuram, Kerala, India. Email: erarchana0@gmail.com
}

Received: 21 November 2019, Revised and Accepted: 25 January 2020

ABSTRACT

Objective: The present study aims to analyze the potential of Aglaia edulis Roxb. leaf extract to induce cytological aberrations in Allium cepa root meristem and to determine the phytoconstituents in the extract.

Methods: Cytotoxicity evaluation of the leaf methanolic extract was done using Allium cepa assay using various concentrations. Volatile phytoconstituents in the extract were determined using gas chromatography-mass spectrometry analysis.

Results: Considerable number of cytomictic cells along with other aberrations was observed. The occurrence of cytomixis was found to be dose dependent where it ranged from $6.58 \pm 0.35$ to $29.45 \pm 0.45$. The percentage of cytomictic cells among the total aberrant cells was observed between $35.19 \pm 1.67$ and $77.39 \pm 1.39$. The phytochemical analysis of the plant extract revealed the presence of active secondary metabolites.

Conclusion: The synergistic action of the active compounds might have triggered the phenomenon of cytomixis which, in turn, could be exploited for the production of polyploids.

Keywords: Aglaia edulis, Cytomixis, Cytological aberrations, Secondary metabolites, Gas chromatography-mass spectrometry, Polyploidy.

(C) 2020 The Authors. Published by Innovare Academic Sciences Pvt Ltd. This is an open access article under the CC BY license (http://creativecommons. org/licenses/by/4. 0/) DOI: http://dx.doi.org/10.22159/ajpcr.2020.v13i3.36429

\section{INTRODUCTION}

Aglaia edulis is a tropical evergreen tree, belonging to the family Meliaceae. It is widely distributed in the tropical forests of Asian countries yet its utility remains underexplored. Some indigenous communities have been reported to use the plant for several purposes. The fruit and aril are used, as they are edible and its pericarp is taken against diarrhea. Wood is used for light construction work locally. A. edulis is a mid-canopy tree that can grow up to $30 \mathrm{~m}$ tall. The genus Aglaia is the only known source of the group of compounds, commonly called rocaglate or rocaglamide derivatives also known as flavaglines. These unique plant compounds have been reported by several researchers for its potential antimicrobial, anthelminthic, and insecticidal properties, as well as for its cytotoxic effect against human cancer cell lines [1].

Cytomixis, migration of cytoplasmic or nuclear materials among adjacent cells, is a complex phenomenon well reported in the microspore cells [2-6]. Cytomixis was observed in different plant groups including pteridophyta, gymnosperms, monocots, and dicots. More specifically, the process was mainly reported in hybrids, aneuploids, polyploids, and mutant individuals [7-10] and that too during the process of microsporogenesis. However, it is also reported in the somatic cells of root and shoot tips [11] and tapetal cells [12] but is less common.

The process of cytomixis involves the migration of cytoplasm, along with the nuclear material of a cell, to its adjacent cell through a connection known as cytomictic channel. Gates [13] assigned the term cytomixis to this cytological event in meiocytes of Oenothera gigas L. This process of inter-pollen mother cell (PMC) transfer of chromatin material was first described in the microsporangia of gymnosperms by Arnoldy [14]. Later, Kornicke [15] reported it during the microsporogenesis in Crocus vernus (L.). The phenomenon has been described for the PMCs of a wide range of flowering plants [16]. On the other hand, cytomictic migration has also been reported in other tissues, such as shoot apex of arboreal plants [17], in the proembryos of graminaceous plants [18], and in the vegetative tissues of anther [19]. Cytomixis was also observed to be of high frequency in transgenic tobacco [20]. Reports also show that herbicides [21] and chemicals [22] might induce cytomictic migration. Some cytotoxic phytoconstituents might also be able to induce cytomixis on meristematic tissues.

The purpose of this work is to investigate the chemical composition and potential of the leaf extract of $A$. edulis to induce cytotoxicity, particularly cytomixis in Allium cepa root meristem. This is the novel report on the cytotoxic effect of A. edulis on A. cepa root meristem.

\section{METHODS}

Preparation of extracts

The leaves of the plant A. edulis were collected from the Kurichiar hills of Wayanad district, Kerala, India. The plant was authenticated at the Department of Botany, University of Calicut, Kerala, India (CALI no. 123757). The leaves were dried in the shade and powdered using an electric blender and stored in a moisture-free atmosphere. Soxhlet extraction of the dried material was done for $6 \mathrm{~h}$ using methanol as solvent and was evaporated to dryness under reduced pressure.

\section{Treatment of root meristem with the extract}

A. cepa bulbs procured from TNAU, Coimbatore, were used for the present study. This was grown in autoclaved moist sand until the root acquires a length of approximately $10 \mathrm{~mm}$. The bulbs were treated with the various concentrations of leaf extracts of $A$. edulis. The concentrations used were $0.5 \%, 0.75 \%, 1 \%, 2 \%$, and $3 \%$ of the leaf extract in distilled water for $24 \mathrm{~h}$. Mitotic squash preparations were done using the modified protocol [23] of Chazotte. The root tips of $20 \mathrm{~mm}$ length were excised at the peak mitotic period and fixed in alcohol:acetic acid (3:1) mixture followed by hydrolysis in $1 \mathrm{~N} \mathrm{HCl} \mathrm{(Merck} \mathrm{Pvt.} \mathrm{Ltd.,} \mathrm{India).} \mathrm{The} \mathrm{fixed}$ roots were incubated in phosphate-buffered saline (PBS) for $15 \mathrm{~min}$ and stained using 4', 6-diamidino-2--phenyl indole (DAPI) (HiMedia Laboratories Pvt. Ltd., India) of $0.1 \mathrm{mg} / \mathrm{mL}$ concentration in dark for $30 \mathrm{~min}$. This was followed by washing in PBS and the squashed root 
meristem was mounted in glycerol. Observations were done using Leica DM6 B system microscope at $\times 40 / 0.80$ magnification and fluorescent imaging was done using Leica DFC 450C camera with the acquisition software Leica LAS X.

\section{Statistical analysis}

Data obtained from the observations were subjected to statistical analyses. One-way ANOVA was performed using Duncan's multiple range test to determine the standard error and significance of treatments, using SPSS version 20. Data were expressed as percentage cytomixis \pm standard error of mean. Cytomixis percentage out of the total aberrant cells as well as the total cells in the field was scored. $\mathrm{p}<0.05$ was considered to be statistically significant.

\section{Gas chromatography-mass spectrometry (GC-MS) analysis}

GC-MS analysis of methanolic leaf extract was carried out on a Varian model CP-3800 GC interfaced with a Varian Saturn 2200 Ion Trap Mass

Table 1: Percentage of chromosomal aberrations and cytomictic cells induced by different concentrations of the leaf extract of Aglaia edulis

\begin{tabular}{llll}
\hline $\begin{array}{l}\text { Conc. } \\
\text { (\%) }\end{array}$ & $\begin{array}{l}\text { \% of } \\
\text { aberration }\end{array}$ & $\begin{array}{l}\text { \% of cytomixis } \\
\text { among total aberrant } \\
\text { cells scored }\end{array}$ & $\begin{array}{l}\text { \% of cytomixis } \\
\text { among total cells } \\
\text { scored }\end{array}$ \\
\hline Control & $1.28 \pm 1.67$ & 0 & 0 \\
0.5 & $16.61 \pm 2.65$ & $35.19 \pm 1.67$ & $6.58 \pm 0.35$ \\
0.75 & $25.17 \pm 0.94$ & $52.24 \pm 2.05$ & $13.83 \pm 0.49$ \\
1 & $29.42 \pm 1.26$ & $53.60 \pm 1.83$ & $15.68 \pm 0.62$ \\
2 & $38.25 \pm 1.05$ & $69.13 \pm 2.95$ & $29.45 \pm 0.45$ \\
3 & $42.51 \pm 3.10$ & $77.39 \pm 1.39$ & $29.45 \pm 0.20$ \\
\hline
\end{tabular}

Spectrometer. Identification of individual components was done using NIST MS library search.

\section{RESULTS}

The cells were counted in each field and photographs were taken. These photographs were analyzed for the percentage of aberrations and this in turn was used for the calculation of the percentage of cytomixis out of the total cells in the field as well as the percentage of cytomixis out of the total aberrant cells. A proportionate increase in the aberration percentage as well as in the cytomictic cell percentage according to the increasing order of the extract concentration was observed (Table 1). Although negligible aberrations were shown in the negative control (distilled water treated roots), cytomixis was totally absent. Various stages of the phenomenon were also traced out by repeated trials and image analyses of the fixed A. cepa meristematic cells were done (Fig. 1).

GC-MS analysis of the leaf extract revealed the presence of potential secondary metabolites in considerable quantity (Table 2). Some of the major phytoconstituents observed were [3-(dimethylamino)phenyl] methanol (14.13\%), Ethyl 3-methyl-2-butenoate (13.92\%), D-alphatocopherol $(10.17 \%), \beta$-methyl- $\alpha, \alpha$-diphenyl-4-morpholine butyric acid (7.82\%), and 0-methyl psychotrine (7.17\%). $\gamma$-sitosterol, a sterol of high pharmacognostic value, was detected in a considerable amount of about $4.37 \%$. Other potential bioactive compounds such as terpenoids (14.94\%) and phenols (3.46\%) were also identified.

\section{DISCUSSION}

The secondary metabolites present in the plant produce cytotoxic effect by disturbing the normal cell cycle [24]. Cytomixis was previously considered as a normal process occurring in the PMCs

Table 2: Phytochemical profile of Aglaia edulis leaf methanolic extract obtained using gas chromatography-mass spectrometry analysis

\begin{tabular}{|c|c|c|c|c|}
\hline S. No. & Compound name & Class & Retention time & Area\% \\
\hline 1. & P-Hydroxyphenyl phosphoric acid & Organic compound & 8.747 & 2.51 \\
\hline 2. & Benzene acetaldehyde & Aldehyde & 10.237 & 0.52 \\
\hline 3. & Mequinol & Phenolic compound & 11.536 & 2.03 \\
\hline 4. & Ethyl 3-methyl-2-butenoate & Ester & 12.236 & 13.92 \\
\hline 5. & 2-Naphthyl- $\beta$-D-galactopyranoside & Glycoside & 12.965 & 0.71 \\
\hline 6. & 7-Propylquinolinine & Quinone & 13.352 & 0.41 \\
\hline 7. & 5-Hydroxypipecolic acid & Organic compound & 13.525 & 1.30 \\
\hline 9. & $\beta$-methyl- $\alpha, \alpha$-diphenyl-4-morpholine butyric acid & Organic compound & 14.493 & 7.82 \\
\hline 10. & 3-(dimethylamino) phenyl] methanol & Alcohol & 15.424 & 14.13 \\
\hline 11. & Copaene & Sesquiterpene & 16.113 & 1.26 \\
\hline 12. & $1,2,3,4,4 a, 5,6,8 a-O c t a h y d r o n a p h t h a l e n e$ & Hydrocarbon & 16.228 & 0.42 \\
\hline 13. & 1-(3,6,6,-Trimethyl-1,6,7,7a-tetrahydrocyclopenta [c] pyran-1-yl) & Ketone & 16.295 & 1.46 \\
\hline 14. & 2,5-Octadecadienoic acid methyl ester & Ester & 16.456 & 0.11 \\
\hline 15. & Isocaryophyllene & Sesquiterpene & 16.610 & 0.42 \\
\hline 16. & Cis-isoeugenol & Phenolic compound & 16.880 & 1.43 \\
\hline 19. & Aciphyllene & Sesquiterpene & 17.357 & 2.02 \\
\hline 20. & Cedrelanol & Terpene & 17.497 & 0.83 \\
\hline 21. & 3-methoxymethyl-2,5,5,8a-tetramethyl-6,7,8a-tetrahydro-5H-chromene & Organic compound & 17.634 & 1.15 \\
\hline 22. & 9-Methoxycalamenene & Organic compound & 17.745 & 0.21 \\
\hline 23. & Gitoxigenin & Steroid & 18.166 & 1.79 \\
\hline 24. & Urs-12-en-28-al,(3-acetoxy)-3 $\beta$ & Terpenoid & 20.396 & 1.03 \\
\hline 25. & $\begin{array}{l}\text { 4,4,6a, 6b, 8a, 11,11,14b-octamethyl-1,4,4a, 5,6,6a, 6b, 7,8,8a, } \\
\text { 10,11,12,12a, 14,14b-octadecahydro-2H-picen-3-one }\end{array}$ & Triterpenoid & 20.459 & 3.93 \\
\hline 26. & Lambda-8 (17),14-diene-13,17-diol & Diterpene & 20.755 & 0.39 \\
\hline 27. & 2,5-Bismethyl-1-silacyclobutyl)-p-xylene & Organic compound & 20.861 & 2.90 \\
\hline 28. & Abieta-6,13-diene & Diterpene & 21.080 & 2.77 \\
\hline 29. & Agathic acid & Diterpenoid & 21.213 & 0.61 \\
\hline 30. & Bicyclo[9.3.1]pentadeca-3,7, dien-12-ol & Organic compound & 21.515 & 0.58 \\
\hline 31. & 3 $\beta$-Pregn-5-ene-3,17, 20-triol & Steroid & 22.454 & 1.70 \\
\hline 32. & 0- methyl psychotrine & Alkaloid & 22.749 & 7.17 \\
\hline 33. & $2,2^{\prime}, 6,6,6^{\prime}, 6^{\prime}, 9,9^{\prime}$-Octamethyl-8, 8'-bitricyclo[5.4.0]undecan & Organic compound & 22.871 & 4.00 \\
\hline 36. & 4,4-dimethyl-cholesta-22, 24-dien-5-ol & Sterol & 30.612 & 0.70 \\
\hline 37. & $\gamma$-Sitosterol & Sterol & 31.598 & 4.37 \\
\hline
\end{tabular}




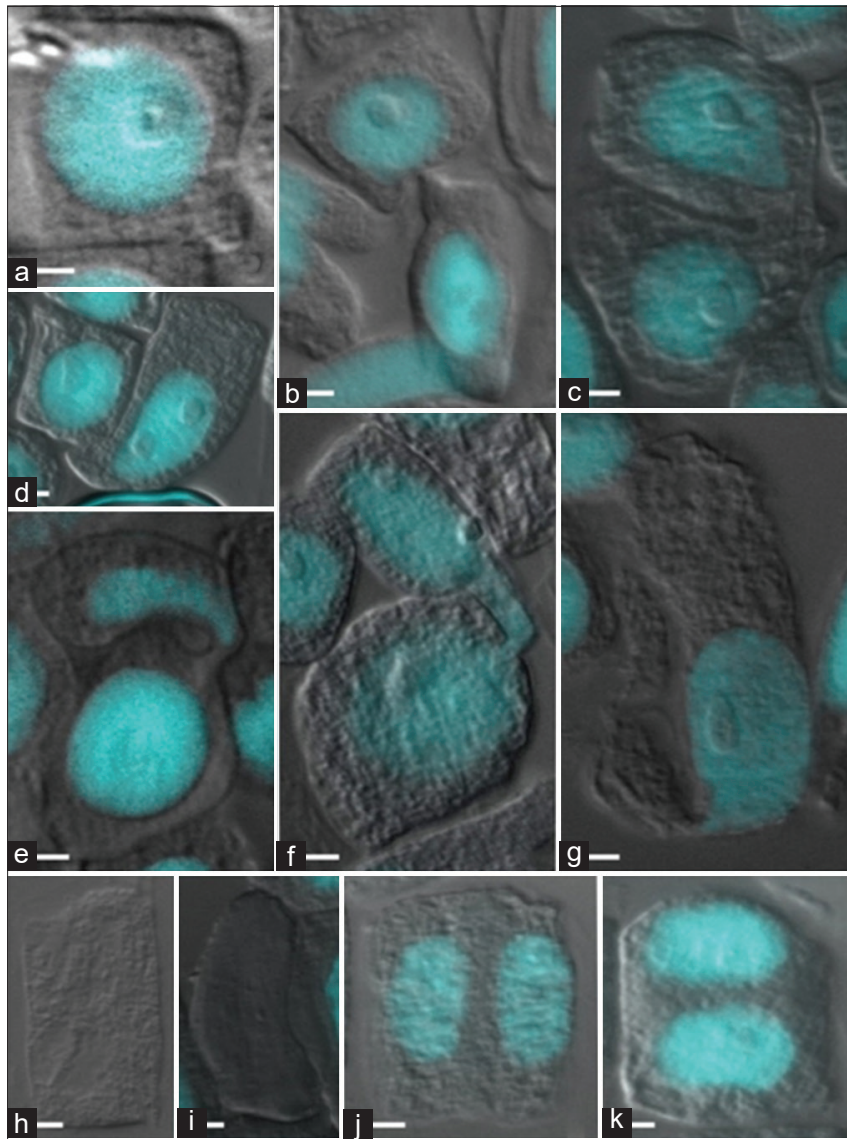

Fig. 1: Various stages of cytomixis induced by Aglaia edulis leaf extract in Allium cepa root meristem: (a) initiation of cytomictic protuberance, (b) cytomictic protuberance, (c) cytomictic channel formation, (d) initiation of cytomictic migration, (e) cytomictic exchange, (f) cytomictic migration of chromatin, (g) cytomictic fusion of nucleus after migration, (h) enucleated donor cell after cytomixis showing the remnants of the channel, (i) enucleated donor cell after cytomixis, ( $\mathrm{j}$ and $\mathrm{k}$ ) binucleate cells after cytomixis, Bar $=10 \mu \mathrm{m}$

only. Recent research revealed that cytomixis might arise in the somatic cells too due to several reasons, namely, the effect of chemical agents such as colchicine [25], methyl methanesulfonate and ethyl methanesulfonate [25], and sodium azide [26]. Evidence obtained also revealed the occurrence of cytomixis due to the use of herbicides [27] and during pathological invasion [21]. It may also arise due to the inhibition of cytokinesis during microsporogenesis. Cytomixis might result in aneuploid, polyploid cells, and binucleate condition. Although these are considered aberrations, now they have acquired importance in plant breeding and improvement efforts. Aneuploid and polyploid crops have been of great interest nowadays for its increased vigor, stress tolerance, buffering of deleterious mutations, and their "gigas effect." The secondary metabolites in the plant extract might be the reason to trigger the phenomenon of cytomixis and this, in turn, was found to be directly proportional to the increasing concentration of the leaf extract of $A$. edulis. The aberration in the mitotic cells was also remarkably hiked according to the increasing concentrations of the extract. The secondary metabolites in the plant extract might hinder the cell cycle by acting against spindle formation, structural and functional proteins involved in the cell cycle, chromatin, or membranes. Although cytological aberrations including both clastogenic and non-clastogenic ones were observed, the most prominent among them was found to be cytomixis. The potential phytoconstituents detected in the leaf extract might be the responsible factors for triggering cytomictic migration in Allium root meristem. This is a novel report that exposes the cytomixis inducing ability of the plant A. edulis. Further investigations are required to elucidate the pathway by which the secondary metabolites induce cytomixis.

\section{CONCLUSION}

Leaf extract of $A$. edulis was proved to be a source of potential bioactive compounds that might have triggered aberrations in Allium root meristem among which cytomixis was found to be the prominent one.

\section{ACKNOWLEDGMENT}

The authors are grateful to the Director, CSIF (Central Sophisticated Instrumentation Facility), University of Calicut, for providing the system microscope facility.

\section{AUTHORS' CONTRIBUTIONS}

AER collected the plant specimen, carried out experimental analyses, and prepared the draft manuscript. JET designed and guided the experimental analyses, edited and finalized the manuscript. Both authors read and approved the manuscript.

\section{CONFLICTS OF INTEREST}

Declared none.

\section{FINANCIAL SUPPORT}

The authors also acknowledge the Council for Science and Industrial Research for providing financial support in the form of Junior Research Fellowship (Grant no: 09/043(0181)/2017-EMR-I).

\section{REFERENCES}

1. Barrera WB Jr. Mitotic activity in root meristem of endemic plant Aglaia luzonensis (Vidal) Merr. and Rolfe. Tilamsik 2016;8:1.

2. Lattoo SK, Khan S, Bamotra S, Dhar AK. Cytomixis impairs meiosis and influences reproductive success in Chlorophytum comosum (Thunb) Jacq.-an additional strategy and possible implications. J Biosci 2006;31:629-37.

3. Singhal VK, Kaur D, Kumar P. Effect of cytomixis on the pollen size in 'Sea buckthorn' (Hippophae rhamnoides L., Elaeagnaceae). Cytologia 2008;73:167-72.

4. Pierre PM, de Souza SM. Cytomixis in plants: Causes, mechanisms and consequences. Braz J Biol Sci 2011;9:231-40.

5. Guan JZ, Wang JJ, Cheng ZH, Liu Y, Li ZY. Cytomixis and meiotic abnormalities during microsporogenesis are responsible for male sterility and chromosome variations in Houttuynia cordata. Genet Mol Res 2012;11:121-30.

6. Mursalimov SR, Deineko EV. How cytomixis can form unreduced gametes in tobacco. Plant Syst Evol 2015;301:1293-7.

7. De Nettancourt D, Grant WF. La cytogénétique de lotus (leguminosae). Cytologia 1964;29:191-5.

8. Gottschalk W. Chromosome and nucleus migration during microsporogenesis of Pisum sativum. Nucleus 1970;13:1-9.

9. De M. Cytomixis in pollen mother cells of an apomictic ornamental Ervatamia divaricata (Linn.) Alston. Cytologia 1983;48:201-7.

10. Li X, Song Z, Feng D, Wang H. Cytomixis in Thinopyrum intermedium, Thinopyrum ponticum and its hybrids with wheat. Cereal Res Commun 2009;37:353-61.

11. Tarkowska J. Cytomiksja w skórce łusek cebuli iw skórce liści oraz w merystemie wierzchołkowym korzenia Allium cepa L. Cytomixis in the epidermis of scales and leaves and in the meristems of root apex of Allium cepa L. Acta Soc Bot Pol 1960;29:149-68.

12. Cooper DC. The transfer of desoxyribose nucleic acid from the tapetum to the microsporocytes at the onset of meiosis. Am Nat 1952;86:219-29.

13. Gates RR. Pollen formation in Oenothera gigas. Ann Bot 1911;25:909-40.

14. Arnoldy W. Contributionsto the morphology of gymnosperms. What are the "germinal vesicle" or "Hofmeister Korperchen" in the egg of Abietineae. Flora 1900;87:194-204

15. Kornicke M. Uber Ortsveranderung von Zellkarnern. New Delhi: SB Niederrhein, Ges, Natureur-und and Heilkunde Bon; 1901. p. 14-25.

16. Kumar G. Induced cytomixis in chickpea (Cicer arietinum L.). Nucleus 2002;45:24-6

17. Kostritsyna TV, Soldatov IV. Cytomixis in apical meristems of Prunus domestica L. $\times$ Persica vulgaris mill. Hybrid' shoots. Genetika 
1991;27:1790-4.

18. Klyuchareva MV. Extrusion of nuclear material in proembryos of gramineous plants (Morphology). USA: Doklady Botanical SciencesAkademiia Nauk; 1983.

19. Wang XY, Yu CH, Li X, Wang CY, Zheng GC. Ultrastructural aspects and possible origin of cytoplasmic channels providing intercellular connection in vegetative tissues of anthers. Russ J Plant Physiol 2004;51:97-106.

20. Sidorchuk YV, Deineko EV, Shumny VK. Peculiarities of cytomixis in pollen mother cells of transgenic tobacco plants (Nicotiana tabacum L.) with mutant phenotype. Cell Tissue Biol 2007;1:570-6.

21. Bobak M. Cytomixis as a manifestation of pathological changes after the application of trifluraline. Nucleus 1978;21:22-6.

22. Dwivedi NK, Sikdar AK, Dandin SB, Sastry CR, Jolly MS. Induced tetraploidy in mulberry I. Cytologia 1986;51:393-401.

23. Chazotte B. In: Yuste R, editor. Imaging: A Laboratory Manual. Cold Spring Harbor, New York, USA: CSHL Press; 2008.

24. Sn PM, Thoppil JE. Evaluation of cytotoxicity and apoptotic potential of Ophiorrhiza pectinata Arn.-a potent anticancer agent. Asian J Pharm Clin Res 2019;12:97-102.

25. Bhat TA, Parveen S, Khan AH. MMS-induced cytomixis in pollen mother cells of broad bean (Vicia faba L.). Turk J Bot 2006;30:273-9.

26. Kumar G, Iadav RS. Induction of cytomixis affects microsporogenesis in Sesamum indicum L. (Pedaliaceae). Ontogenez 2012;43:261-7.

27. Haroun SA. Cytomixis in pollen mother cells of Polygonum tomentosum schrank. Cytologia 1995;60:257-60. 